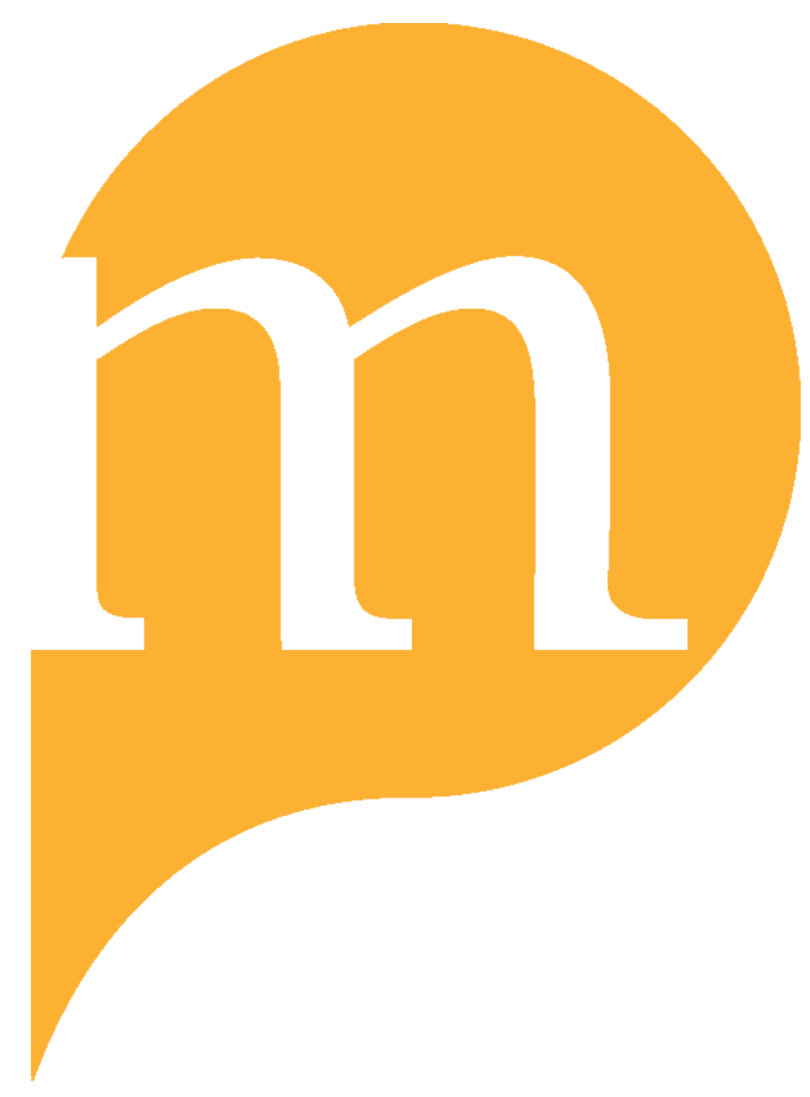

PROJECT MUSE 


\section{The Pleasures and Pitfalls of Colonial Comparisons}

\section{ALEXANDER MORRISON}

Jane Burbank and Frederick Cooper, Empires in World History: Power and the Politics of Difference. xiv +511 pp., maps, illus. Princeton, NJ: Princeton University Press, 2010. ISBN-13 978-0691127088. \$55.00.

Ilya Gerasimov, Jan Kusber, and Alexander Semyonov, eds., Empire Speaks Out: Languages of Rationalization and Self-Description in the Russian Empire. $v i+280$ pp. Leiden: Brill, 2009. ISBN-13 978-9004175716. \$171.00.

Svetlana Gorshenina and Sergei Abashin, eds., Le Turkestan Russe: Une colonie comme les autres? (Russian Turkestan: A Colony Like the Others?). Cahiers d'Asie Centrale, no. 17/18. 548 pp., maps, illus. Paris: Éditions Complexe, 2009. ISBN-13 978-2804801748. €30.00.

Ever since the "Imperial Turn" in Russian history began in the early 1990s, there has been a sense that historians of the Russian Empire were running to catch up with the more developed historiographies of the other great modern and early modern empires-British, French, Habsburg, Qing, Mughal, or Ottoman. Restrictions on archival research, together with the dead hand of Sovietology and the strategic and ideological priorities of the Cold War, meant that much of the existing historiography lacked both empirical rigor and theoretical sophistication and tended either to focus on patterns of Russian aggression and "national" resistance or to reproduce cherished myths of Russian and Soviet exceptionalism. Comparison beyond the borders of the USSR was rare, while the new postcolonial sensibility that informed much research on empires from the 1980 s onward had little or no impact. ${ }^{1}$ These

${ }^{1}$ Of course, some valuable work on Russian imperialism was produced in this period as well. See, for instance, Seymour Becker, Russia's Protectorates in Central Asia: Bukhara and 
deficiencies have been pointed out repeatedly as scholars scrambled to close this gap, and a flood of new works on Russian imperialism and the history of the non-Russian peoples of the empire has transformed the historical landscape. ${ }^{2}$ Nevertheless, the sense has remained that Russian imperial historiography needs to be brought into conformity with that of Africa or South Asia, the main regions of European colonialism, or with that on the Ottoman Empire and its management of different peoples - to "apply the insights" developed in the study of other empires to the Russian case. It is the approach I have taken in most of my own work to date. ${ }^{3}$ It is also that used by many of the contributors to Le Turkestan russe, where the title of Svetlana Gorshenina's introductory historiographical essay (17-76) asks whether or not Russian Turkestan will ever enter into the mainstream of postcolonial studies. ${ }^{4}$

Of all the panaceas offered as a means of rescuing Russia from the margins and bringing it to the center of modern scholarship on empire, the most attractive has been that of "postcolonialism." As with much academic jargon, this is something more often invoked than explained. Broadly speaking, postcolonialism seeks to expose the unequal relationships of power inherent in empire and to explore and explain how these have subsequently shaped the world and the ways in which its peoples and cultures are represented. It generally includes a strong moral and political critique of colonialism and its legacies. This critique is usually confined to a particular variety of supposedly "normative" European maritime colonialism of the 19th century, and until recently land-based or dynastic empires were rarely included. The structures of dominance and hegemony examined by postcolonial scholars did not end with the formal independence of colonized regions but were perpetuated by economic and, above all, cultural means. The discourses that had helped form and sustain empire-notably those emphasizing the racial, religious, and cultural inferiority of colonized peoples, their passivity, laziness, lewdness,

Khiva (Cambridge, MA: Harvard University Press, 1968); Tadeusz Swietochowski, Russian Azerbaijan 1905-1920: The Shaping of National Identity in a Muslim Community (Cambridge: Cambridge University Press, 1985); and the work of Dietrich Geyer, cited below.

2 Indeed, they are now too numerous to list here, but see From the Editors, "The Imperial Turn," Kritika 7, 4 (2006): 705-12.

3 A. S. Morrison, Russian Rule in Samarkand, 1868-1910: A Comparison with British India (Oxford: Oxford University Press, 2008); Morrison, "Applied Orientalism in British India and Tsarist Turkestan," Comparative Studies in Society and History 51, 3 (2009): 619-47.

4 The book is also available online at http://asiecentrale.revues.org/index $1130 . h$ tml (accessed 27 February 2011). Svetlana Gorshenina, "La marginalité du Turkestan colonial russe estelle une fatalité ou l'Asie centrale postsoviétique entrera-t-elle dans le champ des PostStudies?" A Russian version of this essay has been published as "Izvechna li marginal'nost' russkogo kolonial'nogo Turkestana, ili voidet li postsovetskaia Sredniaia Aziia v oblast' postissledovanii?" Ab Imperio, no. 2 (2007): 209-58. 
and general inability to govern themselves-persisted long after its apparent dissolution.

While the best-known theoreticians of postcolonialism-Bernard Cohn, Edward Said, Gayatri Spivak, and others-were mostly either anthropologists or literary critics, these arguments had profound implications for historians. ${ }^{5}$ If the discourses of empire were this powerful, with the ability to shape not just the written record but the very fabric of colonized society, how were historians supposed to penetrate beyond the layers of received wisdom that enveloped the colonial past and avoid simply reproducing colonial discourses and hierarchies? We have been struggling with this problem ever since. At its best, this effort has led to a much greater use of sources (written and oral) in local languages to supplement those written in the "language of power" and to much more careful scrutiny and interpretation of the latter, with the early publications of the Subaltern Studies collective providing an excellent example of how the colonial archive can be read "against the grain" to recover the histories of those who were at the bottom of the imperial pile. ${ }^{6}$ At its worst, it has led to an insistence that this sort of detective work leads merely to another form of elite representation, and that only those colonized groups who produced their own sources can safely be studied by the historian (which in practice leads to an endless succession of articles on intellectual elites, what is unkindly known in an Indian context as Bhadralok Studies), or indeed to an exclusive focus on different forms of colonial representation, with an assumption (spoken or unspoken) that nothing can actually be known about the past. ${ }^{7}$

On one level, nowadays a degree of postcolonial sensibility probably informs the work of almost all historians, as we seek to avoid simply echoing or reproducing the language and narratives of the powerful, and so far as

5 Apart from Edward Said's Orientalism: Western Representations of the Orient (Harmondsworth, UK: Allen Lane, 1978), some of the key texts are Gayatri Chakravorty Spivak, "Can the Subaltern Speak?" in Marxism and the Interpretation of Culture, ed. Cary Nelson and Lawrence Grossberg (Urbana: University of Illinois Press, 1988), 271-313; and Bernard Cohn, Colonialism and Its Forms of Knowledge: The British in India (Princeton, NJ: Princeton University Press, 1996). A useful overview is Ania Loomba, Colonialism/Postcolonialism, 2nd ed. (London: Routledge, 2005).

6 See, for instance, David Arnold, "Rebellious Hillmen: The Gudem-Rampa Risings, 18391924," Subaltern Studies 1 (Delhi: Oxford University Press, 1982): 88-142; and Shahid Amin, "Gandhi as Mahatma: Gorakhpur District, Eastern U.P., 1921-2," Subaltern Studies 3 (Delhi: Oxford University Press, 1984): 1-61.

7 Bhadralok is a Bengali collective term for educated and respectable people. This tendency had already become quite marked in David Arnold and David Hardiman, eds., Subaltern Studies VIII: Essays in Honour of Ranajit Guha (Delhi: Oxford University Press, 1994), critically reviewed by Ramachandra Guha, "Subaltern and Bhadralok Studies," Economic and Political Weekly 30, 33 (19 August 1995): 2056-58. 
the Russian Empire is concerned, works which are influenced by it have been appearing since at least the mid-1990s, often to very good effect. ${ }^{8}$ Many of its dogmas, however, have proved too simplistic and inflexible to accommodate the complex realities even of supposedly "normative" maritime colonial empires, rendering their applicability to the Russian case still more problematic. ${ }^{9}$ Postcolonialism never offered a comprehensive solution to the problems of Russian imperial historiography, and there was always a danger that those who drew on it would simply reproduce its failings. These include a cavalier attitude to empirical research, a tendency to view scholarship as primarily fulfilling a particular political agenda, and an inability to write in plain English. ${ }^{10}$ Another unfortunate aspect of postcolonialism was that it rarely subjected the claims of those nations that replaced imperial polities to the same level of scrutiny as the empires that preceded them and thus, ironically, helped reify 19th-century ideas about the inevitable rise of the nation-state and the inherent illegitimacy of all imperial formations. This point is made in Empire Speaks Out, where the editors turn the argument on its head: "following the logic of postcolonialstyle deconstruction of hegemonic discourses, we argue that empire is itself a 'subaltern' of modern social sciences and humanities because it is forced to speak in analytical and often self-descriptive languages formed by the modernist literary canon" (25-26).

Postcolonialism also decreed that certain types of empire were "modern," and thus truly colonial, whereas others were not. This categorization prevented historians from asking whether, say, British India, Ilkhanid Iran, Ottoman Iraq, or Habsburg Bosnia might perhaps have had anything in common and confined them to what Ann Laura Stoler describes as a "myopic, narrow view of Empire" (Empire Speaks Out, 37). Above all, however, the postcolonial agenda-which was supposed to liberate oppressed colonial subjects from the assumptions and grand narratives of Western historiography-instead often had the effect of entirely depriving them of any agency in their own

${ }^{8}$ I would mention in particular Adeeb Khalid, The Politics of Muslim Cultural Reform: Jadidism in Central Asia (Berkeley: University of California Press, 1997); and Jeff Sahadeo, Russian Colonial Society in Tashkent, 1865-1923 (Bloomington: Indiana University Press, 2007). See also the debate among Adeeb Khalid, Nathaniel Knight, and Maria Todorova on the application of Said's Orientalism to Russia in Kritika 1, 4 (2000): 691-727.

9 This was indeed the conclusion of a recent round-table discussion by Russian and Soviet specialists on the application of the postcolonial paradigm, as they identified points of usefulness but also urged caution: "Roundtable 'Sub Altera Specie': A View at [sic] Postcolonial Paradigm from Inside Russian/Soviet History," Ab Imperio, no. 2 (2008): 80-92.

10 For an amusing critique of some of these tendencies, see Terry Eagleton, "In the Gaudy Supermarket," London Review of Books 21, 10 (13 May 1999): 3-6 (available at www.lrb.co.uk/ v21/n10/terry-eagleton/in-the-gaudy-supermarket, accessed 27 February 2011). 
history. After all, if colonial discourses were truly as powerful as we were led to believe, how could illiterate, uneducated peoples possibly hope to resist them? Equally, some scholars reasoned that, if all the legacies of colonialism were pernicious, then all the more unpleasant aspects of formerly colonized societies, such as the caste system in India, must also, in full or in part, be legacies of colonialism. ${ }^{11}$ This logical fallacy reduced the colonized to the level of infants and completely ignored the complex hierarchies and systems of management through indigenous elites employed by all colonial powers alongside brute force and economic subjugation in order to sustain their rule. ${ }^{12}$ To put it simply, no colonial state was as powerful, practically or ideologically, as it would need to be to enjoy the level of control often attributed to it by postcolonialism, nor was any colonized people as passive and gullible as it would need to be to have its society, mentality, and beliefs manipulated in this way. This point is made with simple clarity by Burbank and Cooper when they write, "The compromises required by empire were stronger than the fantasies of modernizing European colonialism" (329). The study of those compromises, shifts, and accommodations, of the role of local agents in creating and securing imperial regimes, of colonial weaknesssomething particularly identified with the much-misunderstood "Cambridge School” of imperial history founded by Ronald Robinson, Jack Gallagher, and Anil Seal—arguably has as much to offer Russian imperial historiography as postcolonialism does. ${ }^{13}$

11 Probably the most prominent example of this tendency is Nicholas B. Dirks, Castes of Mind: Colonialism and the Making of Modern India (Princeton, NJ: Princeton University Press, 2001).

12 The classic exploration of this is Ronald Robinson, "Non-European Foundations of European Imperialism: Sketch for a Theory of Collaboration," in Studies in the Theory of Imperialism, ed. R. Owen and R. Sutcliffe (London: Longmans, 1972), 117-42.

13 Apart from Robinson's essay cited above, for perhaps the most concise (if overly cynical) statement of this view applied to the British Raj, see Anil Seal, "Imperialism and Nationalism in India," Modern Asian Studies 7, 3 (1973): 326-35, reprinted in a key collection of essays: J. Gallagher, G. Johnson, and A. Seal, eds., Locality, Province, and Nation: Essays on Indian Politics 1870-1940 (Cambridge: Cambridge University Press, 1973). A modern classic of the genre is C. A. Bayly, Empire and Information: Intelligence-Gathering and Social Communication in India, 1780-1870 (Cambridge: Cambridge University Press, 1999). The misunderstandings about the nature of the "Cambridge School" are to a large extent the work of Nicholas Dirks, who in Castes of Mind and The Scandal of Empire (Cambridge, MA: Harvard University Press, 2006) has invented an entirely spurious intellectual pedigree for the "Cambridge School," which links it to the 19th-century historian Sir John Seeley and his famous remark about England having "conquered and peopled half the world in a fit of absence of mind" (The Expansion of England [London: Macmillan, 1883], 10). Not only is there no line of intellectual descent from Seeley to Robinson and Gallagher, but Dirks has never understood what Seeley was actually talking about here, which was the absence of the empire from the historiography of his day, something he wished to rectify. On this point, see D. A. Washbrook, "Reconfiguring 
Borrowing from other fields of imperial history has, on the whole, been highly beneficial for historians of the Russian Empire, the advantages far exceeding the pitfalls. Nevertheless, it is perhaps time we recognized that the growing maturity of the field means that we now have as many insights to offer to historians of the British or French empires as they do to us. While Gorshenina is certainly right in thinking that the very late arrival of postcolonialism in Russian imperial history has led some to persist with the Soviet-era line that an assimilationist Russia was not a colonial power, the absence of any canonical postcolonial texts to be either worshipped or refuted has also allowed historians of Russia to develop their own, more subtle models for examining cultural imperialism, which could yield new insights when applied to other empires. ${ }^{14}$ Ann Laura Stoler (an expert on European colonialism in Southeast Asia but an outsider to the field of Russian history) writes in her contribution to Empire Speaks Out that "Russian history may emerge as a key site to examine that layered quality of imperial formations and the uses to which knowledge of them is and should be put" (55), and arguably it has already done so. Rather than forcing Russian imperial historiography into conformity with that of "typical" European empires, historians now have the confidence to develop their own models of imperial rule based on or influenced by the Russian example and to use them to criticize some of the received wisdoms that have accumulated in the study of the European maritime empires. The often blurred boundaries between colonizer and colonized within the Russian Empire, its bridging of the divide between modern and premodern empires, the complex relationship between its hierarchies of power and categories of ethnicity, religion, or "civilization," its tolerance (or even promotion) of legal and administrative pluralism, and its (perhaps inadvertently) careful management of difference all point to a different model of colonialism than the stern policing of racial and civilizational boundaries that is often seen as typical of Western empires. Yet when we look at the latter more carefully, similar ambiguities often

Indian History," English Historical Review 123, 500 (2008): 156-57. Unfortunately, but understandably enough, for non-South Asianists the Dirksian caricature of the "Cambridge School" has become better-known than the works he denounces: see Jeff Sahadeo, "Visions of Empire: Russia's Place in the Imperial World," Kritika 11, 2 (2010): 408-9.

14 In his review of the Russian translation of Edward Said's Orientalism, which appeared only in 2006, Vladimir Bobrovnikov attacks the way in which Said's ideas have been misused in Russia to suggest that the empire was only ever a victim of Orientalist discourse, never a perpetrator. See Bobrovnikov, "Pochemu my marginaly? Zametki na poliakh russkogo perevoda 'Orientalizma' Eduarda Saida,' Ab Imperio, no. 2 (2008): 325-44. A recent study of a different model of imperialism is Vera Tolz, Russia's Own Orient: The Politics of Identity and Oriental Studies in the Late Imperial and Early Soviet Periods (Oxford: Oxford University Press, 2011). 
begin to emerge, above all if we view them not as an isolated, 19th-century phenomenon, but as just one variety of the oldest, most long-lived form of human political organization.

The latter is precisely what Burbank and Cooper are seeking to do in their enormously ambitious book. As they put it, "this study of empire breaks with the special claims of nation, modernity, and Europe to explain the course of history" (8). "Once we get away from a nation-centered view of history and the assumption that history moves inexorably toward correspondence of one 'people' with one state, we can focus on longstanding debates over what democracy, citizenship, and nationality actually meant, and when, where, and to whom these notions applied-within empires, in inter-empire rivalries, in mobilizations against empires" (221).

Obviously they are not the first historians to question the teleology that sees the recent emergence of nation-states from the wreckage of empires as a natural, desirable, and permanent historical development: apart from a similarly ambitious book by John Darwin, the subtle work of Timothy Snyder on the emergence (or failure) of nationalism in the borderlands between Russia, Prussia, and Austria-Hungary springs to mind; and when it comes to Russia they acknowledge a particular debt to Dominic Lieven and Kimitaka Matsuzato, who for many years have urged that the Russian Empire be understood on its own terms, not simply as a "prison of peoples" or a failed nation-state. ${ }^{15}$ Burbank and Cooper, however, make their argument with remarkable verve, clarity, and scope; and the rare combination of expertise they bring to the question (from Russia to Sub-Saharan Africa) is particularly fruitful. Russia is not at the center of a book that ranges from ancient Rome and China through the Mongols and the Spanish maritime empire, but it does play a crucial bridging role, linking what might seem to be very different types of polity together and demonstrating the ways in which these imperial formations exist on a continuum. In chapter 7 Russia is compared with China, in chapter 9 with the United States, and in all the later chapters it figures as an important point of reference, as an empire that makes nonsense of the various Chinese walls that have been used to create typologies of imperialisms. Instead Burbank and Cooper

\footnotetext{
15 John Darwin, After Tamerlane: A Global History of Empire (Harmondsworth, UK: Allen Lane, 2007), which stresses among other things the simultaneous emergence of modern European commercial empires and the early modern "gunpowder" empires of Eurasia—one of which, that of the Qing, is arguably still with us in a different guise; Timothy Snyder, The Reconstruction of Nations: Poland, Ukraine, Lithuania, Belarus 1559-1999 (New Haven: Yale University Press, 2003); Dominic Lieven, Empire: The Russian Empire and Its Rivals (London: John Murray, 2000); Kimitaka Matsuzato, "Introduction," in his edited Imperiology: From Empirical Knowledge to Discussing the Russian Empire (Sapporo: Slavic Research Center, 2007).
} 
argue that empires deploy a varied repertoire of political practice, culture, and ideology that are all directed toward the same aim-the management of difference. This strikes me as broadly correct, although, of course, in some cases this management can lead to attempts at creating ethnic and cultural homogeneity, whether in the metropole or in settler colonies.

In the course of discussing empire, Burbank and Cooper also explode a good few myths about the genesis of the nation-state, such as the notion that the Peace of Westphalia in 1648 saw the end of woolly or layered concepts of political sovereignty in Europe (182-83). This iconoclasm is refreshing, although they do sometimes get a bit carried away. In a discussion of their book in Ab Imperio Burbank and Cooper tell us something about its genesis within the courses on empire that they taught together first at the University of Michigan, then at New York University. They note their excitement when students began to ask them where the colonized and the colonizer had disappeared to, as proof that they had successfully led them to question and undermine these terms. ${ }^{16}$ This is laudable in many ways, but (as Burbank and Cooper themselves recognize in the book) we cannot dismiss these categories altogether, as in certain contexts (including the Russian) they remain extremely important, and indeed were quite precisely defined in law.

The sheer scale of Burbank and Cooper's work also inevitably leads to some inaccuracies in areas of history with which neither is particularly familiar. To take an example from the field that I know most about, when describing the conquest of Central Asia, they write that "military campaigns defeated Samarkand, Khiva, and Kokand in the 1870s" (355). Samarkand fell to the Russians in 1868, and unlike the latter two it was just a city and had not given its name to a state of which it was the capital (it was part of the Bukharan emirate). This is a very minor point of detail, but Burbank and Cooper go on in the next paragraph to reveal a profound misunderstanding both of the political structures of Central Asia before the conquest and the policies pursued there by the Russians afterward when they write, "The emirate of Bukhara and the khanate of Khiva became 'protectorates,' while Turkestan-where there was no khanate to subordinate-was put under the administration of a military governor-general. As elsewhere the Russians adhered to their practice of co-opting local elites" (355). Turkestan was an administrative creation of the Russians from territory that had mainly been part of the Kokand khanate. Initially, in 1865, they had intended to turn the newly conquered city of Tashkent into the nucleus of a 16 "Interview with Jane Burbank and Frederick Cooper: The Challenge and Serendipity. Writing World History through the Prism of Empire," Ab Imperio, no. 2 (2010): 22-45. 
puppet khanate under Russian protection, but they rapidly realized that this was not politically feasible, leading to the creation instead of a new administrative unit under direct Russian control. The Kokand khanate, reduced to a rump in the Fergana Valley, also survived as a protectorate until 1875, when it was annexed following a revolt directed against the Russian client khan, Khudoyar. It was thus not the case that there was "no khanate to subordinate" in the territory that became Russian TurkestanRussian military action had first destabilized, then destroyed, it. Equally, the Russians did not simply "adhere to their practice of co-opting local elites" in Central Asia-that would imply an incorporation of the region's aristocracy into the Russian nobility on equal terms, as happened with the Baltic Germans or Georgians, and nothing of the kind occurred. Instead Russian rule seems to have led to a rapid eclipse of the Uzbek tribal elites throughout the region, as urban and village oligarchies based on trade and office holding took their place. Although the ulama and religious descent groups maintained their status rather more successfully, it was in the teeth of repeated attempts by the Russian administration to undermine them. ${ }^{17}$ These errors in part simply reflect the variable quality of the secondary literature on 19th-century Central Asia on which Burbank and Cooper are relying, but they also reflect a lack of understanding, visible elsewhere in Burbank's work, that whether in cultural, legal, or administrative terms Turkestan and the Steppe were not just treated differently from European Russia but also treated unequally. ${ }^{18}$

Other specialists will probably find similar inaccuracies when examining the sections of the book that deal with their own particular patch, but I do not think that these detract from the wider argument. In any case, while all scholars of empire will have to engage with the overall thesis of Empires in World History, this is not really a book for the specialist-it is a book for the student and for the intelligent general reader, and as such it is a great success: accessible, well written, and stimulating but eschewing the melodrama and glibness that so often mar works of popular history. Burbank and Cooper have given public access to what their students at Michigan and NYU have been privileged to enjoy over the last twenty years, and on this evidence I can only say that I wish I had been one of them.

Although their focus is much narrower, the editors and contributors to Empire Speaks Out are pursuing an intellectual agenda that has something in common with that of Burbank and Cooper, as they wish to provide a

17 Morrison, Russian Rule in Samarkand, chaps. 1-3.

18 Jane Burbank, "An Imperial Rights Regime: Law and Citizenship in the Russian Empire," Kritika 7, 3 (2006): 397-431. 
"critique of the totalizing analytical categorization of the Russian Empire as a land-based, backward, elite-dependent, and patrimonial polity" (9), and, above all, to understand the empire on its own terms, looking at the "languages of self-description" found in ideology, administrative policy, and intellectual culture:

Instead of describing what empire is, we invite our readers to contemplate what makes certain tropes and discourses imperial. Thus we do not strive to offer a universal theory or a generic definition of empire. Instead we suggest working with a model of the imperial situation defined by the tensions, incongruity, and incommensurability of the languages of selfdescription. By looking closely into the conflicts and overlaps in the polyglossia of explored imperial experience in the Russian Empire we are able to more precisely define the phenomenon of historically constituted diversity as the defining feature of the imperial situation. (23)

This is the thread that is intended to bind together chapters on seemingly rather scattered themes. The opening contribution by Ann Laura Stoler on "Imperial Comparisons" is a written version of some informal comments made at the workshop in Kazan from which the volume emerged. Perhaps in consequence the argument jumps rather bewilderingly from 19th-century French definitions of "colonialism" to Derek Walcott and the identification of colonial "ruins," but if the thread is sometimes hard to follow the effect is never less than stimulating. Stoler offers a welcome external perspective on the historiography of the Russian Empire and a discussion of recent historiographical trends, celebrating Subaltern Studies and deploring both the imperial nostalgia seen in the work of Niall Ferguson and the absence of serious work considering the United States as an imperial formation alongside other empires (although Burbank and Cooper's book represents a huge stride in that direction). Stoler's concern that academic postcolonialism is largely absent from contemporary American political debate and foreign policy (34) does come across as rather pious and self-important (and ensures the piece already seems a little dated). It also seems odd that in a volume which is a product of an international collaborative project the list of 20 works that are held to characterize recent scholarship on the Qing, Ottoman, and Russian empires (48) consists exclusively of books published in the United States. Overall though, this is a robust exploration of the value of imperial comparisons and offers numerous flashes of insight into the nature of cultural imperialism.

Three of the subsequent chapters are focused primarily on intellectual history: that by Marina Mogil'ner-a summary in English of the more 
detailed arguments and material from her recent monograph on Russian physical anthropology-is perhaps the best in the volume. ${ }^{19}$ In it she subjects the "Sonderweg" interpretation of Russian thinking on race to a sustained and effective critique, demonstrating both that certain branches of Russian physical anthropology (exemplified by Professor Ivan Alekseevich Sikorskii in Kiev) did indeed develop a fully fledged system of racial categorization, while "many European physical anthropologists reacted negatively to overt attempts at constructing racial hierarchies, to the 'scientific' glorification of the Aryan race, and later on to crude Social-Darwinist schemes" (160). This meant that the contrasting "liberal anthropology" or "anthropology of imperial diversity" (166), which flourished at Moscow University, was not peculiar to Russia either. Ilya Gerasimov's exploration of the development and application of the idea of "social engineering" traces its intellectual genealogy from North America to late imperial Russia and demonstrates convincingly that even at a relatively humble level Russian intellectual life was far from isolated from the Western world and drew upon common ideas of modernity. Finally, Hans-Christian Petersen examines the intellectual debates between and representations of Russia by members of Poland's intellectual elite in the 1840 s and 1850 s, concluding that they "cannot be simply forced into the model of a Polish-Russian antagonism" (119).

Other chapters are more focused on politics and administration: Kusber argues that Catherine the Great's educational policies, rather than being judged by the yardstick of national modernization, should be understood as a sensible and pragmatic response to the empire's heterogeneity (88); and Glebov, in a fruitful study of Siberian "Middle Ground," comes to a conclusion reminiscent of the "Cambridge School" when he writes of the unintended outcomes of imperial initiatives and the crucial role played by local agency in determining Russian policy (126). In all these contributions one can see a coherent intellectual agenda that seeks to understand Russian imperialism on its own terms without sacrificing critical distance.

The thread linking the chapters of this volume is still quite slender, however, and at times it breaks altogether, not least because some of the papers have a tendency to descend into a welter of overtheorizing about Russia's place among the empires, which seems to have only the most tenuous link to the evidence presented, and because the language is often painfully convoluted and opaque ("strategic relativism may provide the basis for a network type of horizontal mobilization in a differentiated environment as

${ }_{19}$ Marina Mogil'ner, Homo imperii: Istoriia fizicheskoi antropologii v Rossii (Moscow: Novoe literaturnoe obozrenie, 2008)—reviewed by Nathaniel Knight in Kritika 12, 3 (2012): 667-83. 
well as an obstacle to creating an unambiguous state of belonging" [23]). The other problem is that in their anxiety to understand the empire on its own terms some of the arguments in Empire Speaks Out come dangerously close to reproducing uncritically tsarist and Soviet discourses about Russian exceptionalism and tolerance (something also seen in Robert Crews's contribution to Le Turkestan russe). Although the editors are fully aware of this danger, writing, "taking languages of self-description seriously does not mean taking them at face value" (25), there are places where contributors fall into precisely this trap. In his essay on the Russian State Duma as "the real and live ethnographic map of Russia," Alexander Semyonov claims that the fact that Turkestan, the Caucasus, and Siberia were all represented in the First Duma, while only the Grand Duchy of Finland, Bukhara, and Khiva were excluded, clearly distinguishes Russia from the European maritime empires, with their supposedly rigid distinction between metropole and colony:

The simultaneous presence of Central Asian protectorates and the Grand Duchy of Finland in the same category of exclusion defies the notion of a rigid colonial boundary as constitutive of Russian imperial rule. This is not to say that the discourse of cultural and civilizational hierarchy was lacking in late imperial Russia, it simply means that this discourse failed to destabilize the formal rationality of government-focused conception of imperial sovereignty and failed to substantively penetrate the political logic of inclusion and exclusion in the process of re-shaping the political space of the Russian Empire from above at the beginning of the twentieth century. (201)

This is wrong at a number of levels: first, Semyonov fails to recognize that although Turkestan was represented in the First Duma, the franchise was much more restricted than in European Russia and heavily skewed to favor Europeans, who elected more deputies than the Muslims despite making up barely 4 percent of the population in the region. He also neglects to mention that the First Duma was dissolved before any representatives could be elected from Central Asia, that the franchise for the Second Duma was still more restricted, and that thereafter Turkestan and the Steppe region were in fact excluded from representation altogether. ${ }^{20} \mathrm{He}$ also overlooks the absence of zemstvos throughout Asiatic Russia and the fact that Finland had representative institutions of its own, while the Central Asian protectorates

${ }^{20}$ Khalid, The Politics of Muslim Cultural Reform, 233-35; Diliara M. Usmanova, "The Activity of the Muslim Faction of the State Duma and Its Significance in the Formation of a Political Culture among the Muslim Peoples of Russia (1906-1917)," in Muslim Culture in Russia and Central Asia, 2: Inter-Regional and Inter-Ethnic Relations, ed. Anke von Kügelgen, Michael Kemper, and Allen J. Frank (Berlin: Klaus Schwarz, 1998), 417-55. 
did not. The story of the shrinking Duma franchise and the withholding of such limited representative government as did exist in the Russian Empire from the overwhelming majority of its Muslim population in fact offers some very interesting parallels with the maritime empires, where boundaries between metropole and colony could indeed be similarly blurred (as in the cases of Algeria and Ireland).

Although it has a much more specific geographical focus than either of the other two volumes considered here, the long-awaited special issue of Cahiers d'Asie Centrale on Russian Turkestan is similarly concerned with questions of imperial categorization and Russia's place in a wider colonial world. ${ }^{21}$ Most historians (at least in the West) have long acknowledged that Turkestan was the region where the Russian Empire looked more colonial than anywhere else, and indeed the question incorporated in the title (A colony like the others?) is founded on precisely the notion of a normative form of European colonialism that Burbank and Cooper are attacking. Gorshenina and Abashin (and among the contributors, Khalid), however, make a good case both for the salience of this idea in certain cases and for its applicability to Turkestan. Arguably there is a distinctive type of European imperialism that emerges in the 18th and 19th centuries: a maritime empire with a clear distinction between metropole and colony, visible in cultural, linguistic, and ethnic terms and enshrined in law. Many historians would also assert-following J. A. Hobson, V. I. Lenin, and, more recently, P. J. Cain and A. G. Hopkins-that it has a particularly close relationship with finance and industrial capitalism. ${ }^{22}$ It will have some notion of a "civilizing mission" and employ this and other Enlightenment discourses to legitimate its rule. It will have varying hierarchies of political rights based largely on race; and at its heart will lie a nation-state, in the name of whose privileged titular nationality all these territories will be held. ${ }^{23}$ All of this then contributes to a clear and insuperable barrier between ruling and

21 I should note here that I have analyzed many of the individual contributions to this volume in more detail in a single review for Ab Imperio, no. 3 (2010): 345-50.

22 J. A. Hobson, Imperialism, a Study (London: Cassell, 1902); V. I. Lenin, Imperialism: The Highest Stage of Capitalism (Moscow: Progress, 1982); P. J. Cain and A. G. Hopkins, "Gentlemanly Capitalism and British Expansion Overseas I: The Old Colonial System, 16881850," Economic History Review 39, 4 (1986): 501-52; Cain and Hopkins, "Gentlemanly Capitalism and British Expansion Overseas II: New Imperialism, 1850-1945," Economic History Review 40, 1 (1987): 1-26.

23 It is often suggested that the nation-state, with its internal and external colonizing projects that seek to remake subjects and citizens and erase their "backwardness," is a defining feature of modern imperialism, although it also derives much of its force from the romantic reaction against the Enlightenment. See Peter van der Veer, "The Global History of 'Modernity,' " and David Washbrook, “The Global History of 'Modernity': A Response to a Reply," Journal of the Economic and Social History of the Orient 41, 3 (1998): 289, 305. 
subject peoples-the divide between colonizer and colonized which Burbank and Cooper's students were so disconcerted to lose sight of does not always become invisible on closer scrutiny, and indeed this entire model of empire is based on ideas of difference, clear boundaries, and demarcations, however difficult these often were to uphold in practice in the face of 19th-century ideas about universal human political rights. ${ }^{24}$

To construct an ideal type of this kind against which to compare Russia (or indeed any other empire) is not in itself a problem. Difficulties arise only when (a) one allows the type to obscure the much messier reality, and (b) one assumes that the type is a norm that represents the majority of imperial formations-which, as Burbank and Cooper demonstrate, it does not. By and large, the contributors to Le Turkestan russe manage to avoid both these pitfalls, drawing on the literature from other empires where relevant, demonstrating which elements Russian Turkestan did indeed have in common with other European colonies, but not attempting to force it into a theoretical straitjacket. The best contributions (Gorshenina on the Turkestan exhibitions of the 1860s, Abashin on the "Sart Question," Sahadeo on colonial Tashkent, Khalid on culture and power, Komatsu on Muslim intellectual responses to Russian rule, Sophie Hohmann on colonial medicine, Paolo Sartori on the qazis' courts, Carole Ferret on the rearing of "horses for the empire," and Cloé Drieu on early Uzbek cinema) all show a deft awareness of both imperial commonalities and Central Asian specificities and, unsurprisingly, are rooted in deep empirical research in the region.

Le Turkestan russe is thus a useful and valuable volume, but it does not quite succeed in becoming more than the sum of its parts. To some degree, this is because almost half of the contributions have already been published more or less in full elsewhere (apart from Gorshenina's historiographical essay, this is true of the pieces by Abashin, Laruelle, Komatsu, Pravilova, Sahadeo, and Schimmelpenninck van der Oye). ${ }^{25}$ Primarily, however, it is because, in

${ }^{24}$ Frederick Cooper and Ann Laura Stoler, "Between Metropole and Colony: Rethinking a Research Agenda," in their edited Tensions of Empire: Colonial Cultures in a Bourgeois World (Berkeley: University of California Press, 1997), 1-56.

25 Sergei Abashin, Natsionalizmy v Srednei Azii: V poiskakh identichnosti (St. Petersburg: Aleteiia, 2007); Marlène Laruelle, Mythe aryen et rêve impérial dans la Russie du XIXe siècle (Paris: CNRS, 2005); Komatsu Hisao, "Dar al-Islam under Russian Rule as Understood by Turkestani Muslim Intellectuals," in Empire, Islam, and Politics in Central Eurasia, ed. Uyama Tomohiko (Sapporo: Slavic Research Center, 2007): 3-21; Ekaterina Pravilova, "Reka imperii: Amudar'ia v geopoliticheskikh i irrigatsionnykh proektakh vtoroi poloviny XIX veka," in Aziiatskaia Rossiia: Liudi i struktury imperii, ed. N. G. Suvorova (Omsk: Izdatel'stvo Omskogo gosudarstvennogo universiteta, 2005): 425-57; Jeff Sahadeo, "In Search of the Russian Nation: Notes from the Periphery," Canadian Review of Studies in Nationalism 31,1-2 (2004): 113-26; 
common with recent trends in Russian imperial historiography, the focus is overwhelmingly cultural. With the exception of Carole Ferret's wonderful essay on tsarist-era horse breeding we learn nothing at all about agriculture, taxation, or trade from Le Turkestan russe; and consequently a crucial aspect of the debate over Turkestan's colonial status-whether or not it was exploited economically for the benefit of the Russian metropole-is not addressed at all. ${ }^{26}$ Twenty years after serious research on 19th-century Central Asia began in the West, we are still stuck with a Soviet-era narrative when it comes to understanding social and economic change in the tsarist period. This begins with the Russians conquering the region at the behest of the Moscow textile manufacturers in order to secure a source of raw cotton and a captive market for shoddy Russian industrial goods, a canard which should long ago have been laid to rest. ${ }^{27}$ It has no basis whatsoever in evidence and is instead derived from the reworking by Lenin of J. A. Hobson's thesis about the machiavellian (and Jewish) financiers who he believed had engineered the Boer War. ${ }^{28}$ American cotton would not be grown widely in Turkestan until the 1890s, and apparently it was only high tariffs on imported cotton and generous tax breaks that rendered it profitable. ${ }^{29}$ The principal beneficiaries seem to have been the imperial exchequer and the local entrepreneurs who set up cottoncleaning mills and loaned money and seeds to the peasant cultivators who grew it on their smallholdings. The Moscow textile barons (who even in the last years of tsarism were quite incapable of exercising significant political

David Schimmelpenninck van der Oye, Russian Orientalism: Asia in the Russian Mind from Peter the Great to the Emigration (New Haven: Yale University Press, 2010): 74-91-reviewed by Aleksandr Polunov in Kritika 12, 3 (2012): 736-44.

26 The latest research on agrarian relations in Turkestan is Beatrice Penati, "Swamps, Sorghum, and Saxauls: Marginal Lands and the Fate of Russian Turkestan (c. 1880-1915)," Central Asian Survey 29, 1 (2010): 61-78; and Penati, "Notes on the Birth of Russian Turkestan's Fiscal System: A View from the Fergana Oblast," Journal of the Economic and Social History of the Orient 53, 5 (2010): 739-69.

27 See N. A. Khalfin, Politika Rossii v Srednei Azii (1857-1868) (Moscow: Izdatel'stvo Vostochnoi literatury, 1960). The persistence of this notion can be gauged by the fact that it even finds a mention in Marco Buttino's otherwise outstanding Revoliutsiia naoborot: Sredniaia Aziia mezhdu padeniem tsarskoi imperii i obrazovaniem SSSR (Moscow: Zven'ia, 2007), 18.

28 A. M. Eckstein, "Is There a 'Hobson-Lenin Thesis' on Late Nineteenth-Century Colonial Expansion?” Economic History Review 44, 2 (1991): 306-7.

29 Graf K. K. Palen, Otchet, revizuiushchego, po Vysochaishemu poveleniiu, Turkestanskogo kraia (St. Petersburg: Senatskaia tipografiia, 1909), 5: Nalogi i poshliny, 75; S. N. Abashin, "Sotsial'no-ekonomicheskoe i demograficheskoe razvitie," in Tsentral'naia Aziia $v$ sostave Rossiiskoi imperii, ed. Abashin, D. Iu. Arapov, and N. E. Bekmakhanova (Moscow: Novoe literaturnoe obozrenie, 2008), 147. 
influence) appear simply to have ended up paying a higher price for their raw cotton. ${ }^{30}$

The effects of the cotton boom in Turkestan itself are also poorly understood: by 191470 percent of arable land in Fergana was under cotton, meaning that the region was increasingly dependent on imported grain. In 1916-17, when grain imports from Semirechie and Siberia dried up, this led to devastating famine; and it has often been interpreted as something deliberately designed to foster a relationship of colonial dependence, not least because it appeared to be a forerunner of similar Soviet policies. ${ }^{31}$ However, before 1914 there is no evidence of any state coercion in the growing of cotton; peasants appear to have switched to it in large numbers because thanks to the favorable fiscal regime it was extremely profitable. Dependence on imported food is hardly evidence of a subordinate, colonial relationship - under that criterion Britain had become a colony of Argentina by 1914. Equally, we do not really understand what the social effects of the cotton boom were: Soviet historians invariably argued that it led to a concentration of land in ever fewer hands, an increase in landless laborers and sharecroppers, and the growth of class stratification in the countryside. ${ }^{32}$ This is not an impossible scenario, but given the ideological necessity to come to this conclusion it ought to be treated with caution. Collated statistics for this period are notoriously unreliable, but they appear to show that overwhelmingly cotton was cultivated by smallholders on their own plots of land, although this does not rule out exploitation through various forms of debt bondage. ${ }^{33}$ Overall, the steady increase of land area under cultivation, expansion of irrigation and large flows of inward migration to Turkestan from Kashgaria, Afghanistan,

30 This is borne out in Muriel Joffe's "Autocracy, Capitalism, and Empire: The Politics of Irrigation," Russian Review 54, 3 (1995): 365-88, which details how a scheme by Moscow mill owners to acquire their own large cotton-growing estates in Turkestan and employ local labor (rather than relying on cotton grown on peasant smallholdings, as 90 percent of it was) was stymied by administrative opposition.

31 Marco Buttino, "Study of the Economic Crisis and Depopulation in Turkestan, 19171920," Central Asian Survey 9, 4 (1990): 59-74; Buttino, "Economic Relationships between Russia and Turkestan, 1914-1918, or How to Start a Famine," in Transforming Peasants: Society, State, and the Peasantry, 1861-1930, ed. Judith Pallot (London: Macmillan, 1998), 194-209; Sahadeo, Russian Colonial Society, 200-7.

32 See, for instance, A. S. Iuldashev, Agrarnye otnosheniia v Turkestane (konets XIX-nachalo XX vv.) (Tashkent: Uzbekistan, 1969). The same argument is put forward in Tsentral'naia Aziia $v$ sostave Rossiiskoi imperii, 187-209.

33 V. Knize and M. Iuferev, "Khlopkovodstvo," Aziiatskaia Rossiia, 2: Liudi i poriadki za Uralom (St. Petersburg: Izdatel'stvo pereselencheskogo upravleniia, 1914), 285-86; Prilozheniia $k$ Otchetu po revizii Turkestanskogo kraia, proizvedennoi Vysochaishemu poveleniiu Senatorom Gofmeisterom Grafom K. K. Palenom, 19: Materialy k kharakteristike narodnogo khoziaistvav Turkestane, pt. 1, div. 1 (St. Petersburg: Senatskaia tipografiia, 1911), 328-29, 338. 
and Iran in this period all suggest that the local economy was flourishing until 1914.

Unfortunately, the two articles in Le Turkestan russe that might have shed some light on these vital points fail to do so: Ekaterina Pravilova has done valuable and pioneering work elsewhere on the relative fiscal contributions of different parts of the empire to the imperial budget (with Turkestan a major deficit area for almost the whole imperial period, propped up by large subsidies from the center), but her contribution here on the vital topic of irrigation concentrates on the more or less fantastic Russian projects to divert the Amu Darya to its "original course," and leaves the reader with the impression that prior to the Russian arrival irrigation in Turkestan was negligible. ${ }^{34}$ In fact, the reverse is the case: the pre-existing canal network in Central Asia dwarfed anything built by the Russians and remained largely impenetrable to them. It was the great canals built by the khans of Kokand in the 18th and 19th centuries, before the conquest, that made the cotton boom possible. François Lantz's piece on the Transcaspian Railway, meanwhile, is overly theoretical, more interested in the perception of space than the military and commercial significance of the railway, and is in any case crippled by a total absence of sources in Russian.

This economic myopia seems to be a general failing of what is sometimes called the "New Imperial History" of Russia and Eurasia, perhaps because of an over-reaction against the materialist approaches of Soviet historiography. More than 30 years after its original publication, the only systematic attempt in Western scholarship to analyze Russian imperialism in economic terms remains that of Dietrich Geyer. ${ }^{35}$ Better access to archival sources means that elements of his thesis could now be tested much more thoroughly, but little such work has been done (and I have been as guilty as anyone in neglecting this). If the political and cultural history of Russian imperialism can now stand comparison with that of any empire, and indeed in its subtlety and absence of polemic is often superior, when it comes to the analysis of the economic drivers of imperial expansion (or lack of them), the role played by imperialism in the spread of international capitalism, and its impact on

34 Ekaterina Pravilova, “'Tsena' imperii: Tsentr i okrainy v rossiiskom biudzhete v XIXnachalo XX vv.," Ab Imperio, no. 4 (2002): 115-44; Pravilova, Finansy imperii: Den' gi i vlast' $v$ politike Rossii na natsional 'nykh okrainakh, 1801-1917 (Moscow: Novoe izdatel'stvo, 2006). For an interesting point of comparison, see Avner Offer, "The British Empire, 1870-1914: A Waste of Money?” Economic History Review 46, 2 (1993): 215-38.

35 Dietrich Geyer, Der Russische Imperialismus: Studien über d. Zusammenhang von innerer $u$. auswärtiger Politik 1860-1914 (Göttingen: Vandenhoeck \& Ruprecht, 1977), published in English as Geyer, Russian Imperialism: The Interaction of Domestic and Foreign Policy, 1860 1914, trans. Bruce Little (Leamington Spa: Berg, 1987). 
agriculture, irrigation and the land, historians of the Russian Empire still have a good deal to learn. ${ }^{36}$

Dept. of History

University of Liverpool

9 Abercromby Square

Liverpool L69 7WZ, UK

A.S.Morrison@liverpool.ac.uk

When the publications of a Kritika staff member are reviewed, that person is excluded from all editorial decisions associated with the review.

36 R. Robinson and J. Gallagher, "The Imperialism of Free Trade," Economic History Review 6, 1 (1953): 1-15; P. J. Cain and A. G. Hopkins, British Imperialism: Innovation and Expansion, 1688-1914 (London: Longmans, 1993); Cain and Hopkins, British Imperialism: Crisis and Deconstruction, 1914-1990 (London: Longmans, 1993); H. Bonin, C. Hodeir, and J.-F. Klein, eds., L'Esprit économique impérial (1830-1870) (Paris: Publications de la Société française d'Histoire d'Outre Mer, 2008); Jacques Marseille, Empire colonial et capitalisme français: Histoire d'un divorce (Paris: Albin Michel, 1984). On the impact of imperialism on agriculture, see, for instance, Dharma Kumar, Land and Caste in South India: Agricultural Labour in the Madras Presidency during the Nineteenth Century (Cambridge: Cambridge University Press, 1965); Eric Stokes, The Peasant and the Raj: Studies in Agrarian Society and Peasant Rebellion in Colonial India (Cambridge: Cambridge University Press, 1980); David Washbrook, "Law, State, and Agrarian Society in Colonial India," Modern Asian Studies 15, 3 (1981): 649-721; Haile M. Larebo, The Building of an Empire: Italian Land Policy and Practice in Ethiopia, 19351941 (Oxford: Clarendon, 1994); Richard Saumarez Smith, Rule by Records: Land Registration and Village Custom in Early British Panjab (Delhi: Oxford University Press, 1996); Haruka Yaganisawa, A Century of Change: Caste and Irrigated Lands in Tamilnadu, 1860s-1970s (Delhi: Manohar, 1996); Dharma Kumar, Colonialism, Property, and the State (Delhi: Oxford University Press, 1998); Tirthankar Roy, Traditional Industry in the Economy of Colonial India (Cambridge: Cambridge University Press, 1999); Roy, The Economic History of India, 18571947 (Delhi: Oxford University Press, 2006); and Timothy Mitchell, Rule of Experts: Egypt, Techno-Politics, Modernity (Berkeley: University of California Press, 2002). 